\title{
Correction to: Nrf2 activation through the PI3K/GSK-3 axisprotects neuronal cells from $A \beta$-mediatedoxidative and metabolic damage
}

\author{
Krystal Sotolongo ${ }^{1}$, Jorge Ghiso ${ }^{1,2^{*}+}$ and Agueda Rostagno $0^{1 *+}$
}

\section{Correction to: Alzheimers Res Ther (2020) 12:13 \\ https://doi.org/10.1186/s13195-019-0578-9}

After the publication of this article [1], we became aware that there were errors in Figs. 4 and 13.

Specifically: Figure 4: instead of displaying the appropriate images, the $1 \mu \mathrm{M} \mathrm{A} \beta+$ Trolox panel duplicated the NoA $\beta+\mathrm{MTZ}$ image and the $1 \mu \mathrm{M} A \beta+\mathrm{MTZ}$ panel duplicated the $10 \mu \mathrm{M}$ $\mathrm{A} \beta+\mathrm{MTZ}$ image. Both errors have been corrected.

Figure 13: the Trolox+SB216763 panel that inadvertently duplicated the Noactivator+SB216763 image has been replaced. There was also an imbalanced resizing of the NoInhibitor+MEL panel which has now been replaced for a different original image from the same experiment. The correct Figures 4 and 13 are shown below.

\section{Author details}

'Department of Pathology, New York University School of Medicine, 550 FirstAvenue, New York, NY 10016, USA. ²Department of Psychiatry, New YorkUniversity School of Medicine, 550 First Avenue, New York, NY 10016, USA.

Published online: 24 March 2020

\section{Reference}

1. Sotolongo K, et al. Nrf2 activation through the PI3K/GSK-3 axisprotects neuronal cells from $A \beta$-mediatedoxidative and metabolic damage. Alzheimers Res Ther. 2020;12:13 https://doi.org/10.1186/s13195-019-0578-9.

The original article can be found online at https://doi.org/10.1186/s13195019-0578-9

* Correspondence: jorge.ghiso@nyumc.org; agueda.rostagno@nyumc.org

${ }^{\dagger}$ Jorge Ghiso and Agueda Rostagno contributed equally to this work.

'Department of Pathology, New York University School of Medicine, 550 FirstAvenue, New York, NY 10016, USA

Full list of author information is available at the end of the article

(C) The Author(s). 2020 Open Access This article is licensed under a Creative Commons Attribution 4.0 International License, which permits use, sharing, adaptation, distribution and reproduction in any medium or format, as long as you give appropriate credit to the original author(s) and the source, provide a link to the Creative Commons licence, and indicate if changes were made. The images or other third party material in this article are included in the article's Creative Commons licence, unless indicated otherwise in a credit line to the material. If material is not included in the article's Creative Commons licence and your intended use is not permitted by statutory regulation or exceeds the permitted use, you will need to obtain permission directly from the copyright holder. To view a copy of this licence, visit http://creativecommons.org/licenses/by/4.0/ The Creative Commons Public Domain Dedication waiver (http://creativecommons.org/publicdomain/zero/1.0/) applies to the data made available in this article, unless otherwise stated in a credit line to the data. 


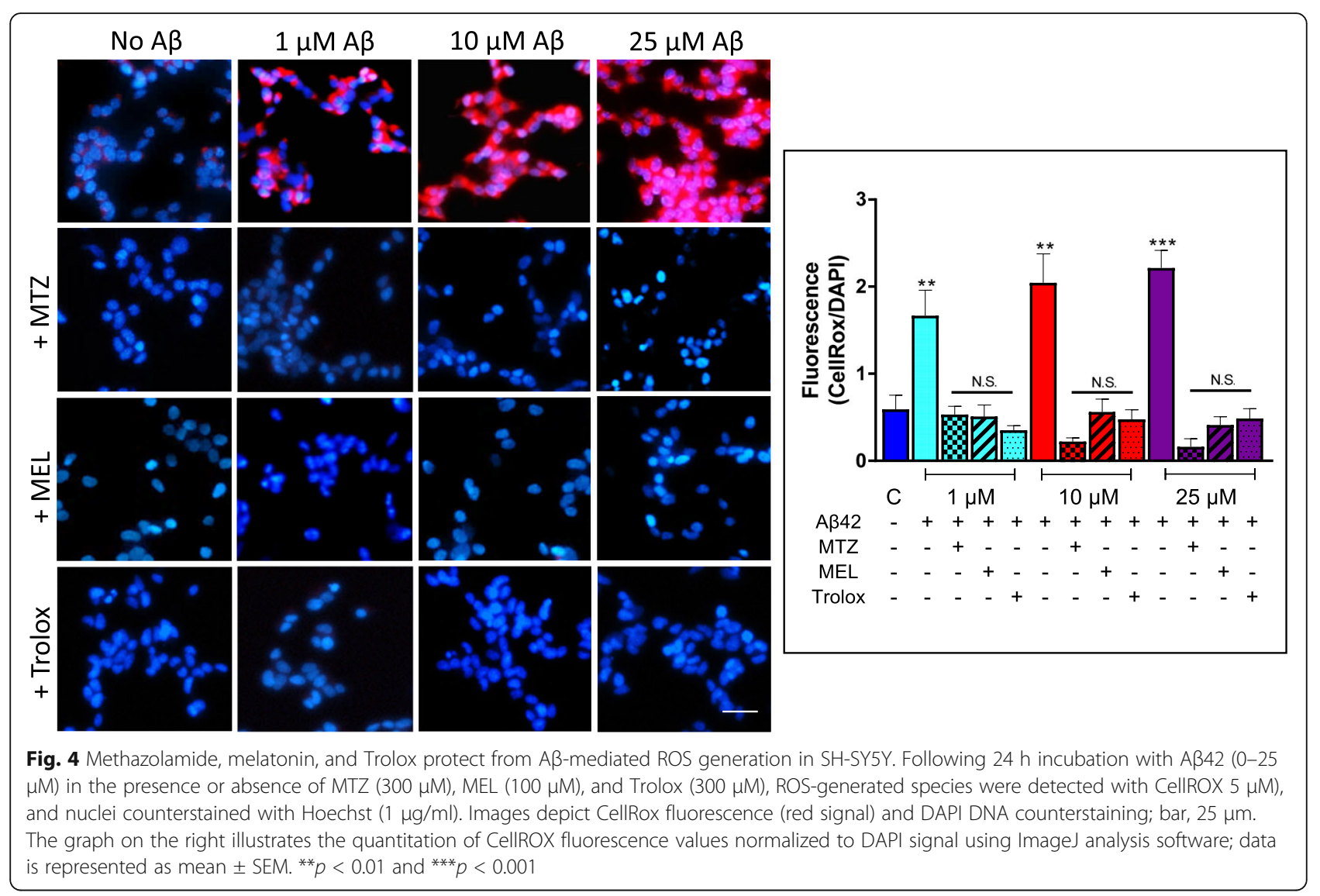




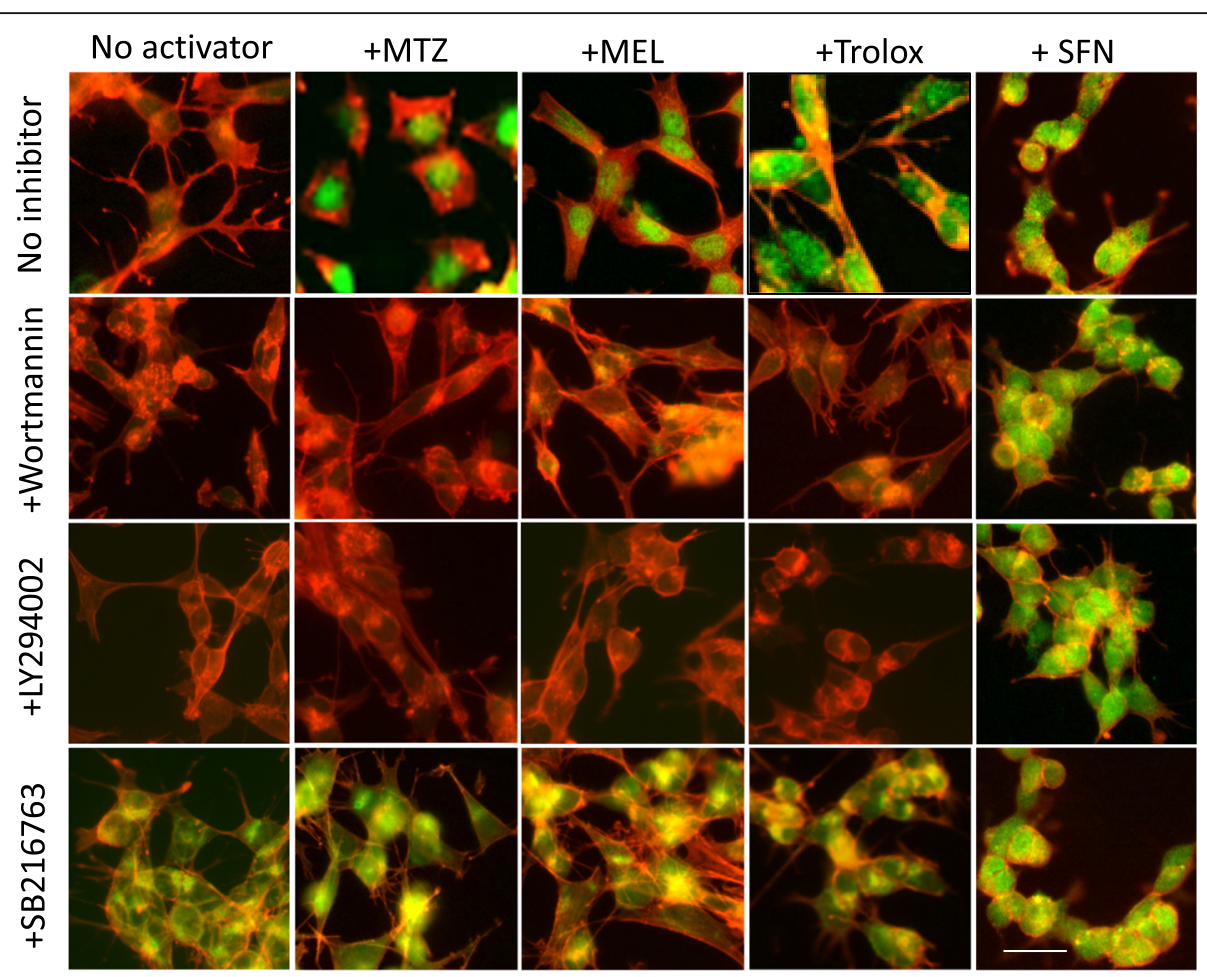

Fig. 13 Methazolamide, melatonin, and Trolox activate Nrf2 through a PI3K-mediated pathway. SH-SY5Y cells were treated with MTZ (300 $\mu M$ ),

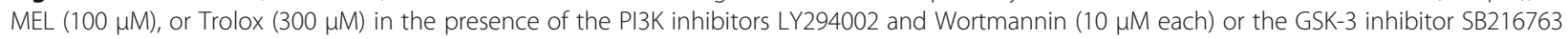
$(10 \mu \mathrm{M})$. As a control, cells were incubated with SFN $(5 \mu \mathrm{M})$, a compound capable of activating Nrf2 through disruption of its binding to Keap-1, a PI3K-independent pathway. In all cases, Nrf2 expression was evaluated by immunocytochemistry as in Figs. 7 and 8. Green fluorescence highlights Nrf2 nuclear translocation, and red fluorescence depicts actin staining with Alexa 588-conjugated phalloidin. Bar represents $20 \mu \mathrm{m}$ in all images. Quantitation of the nuclear fluorescence signal is shown in Additional file 2: Figure S2 